\title{
CNA
}

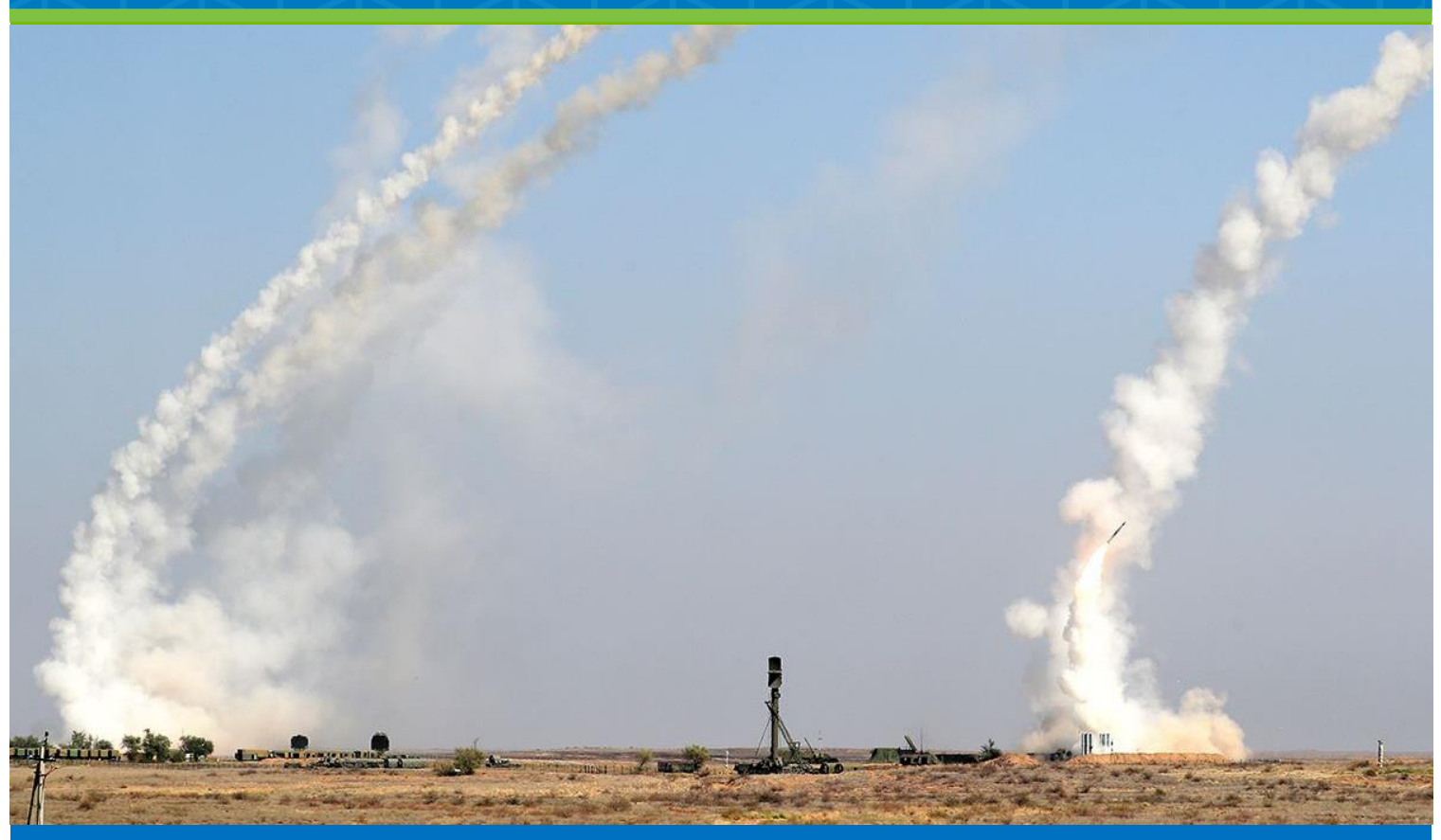

Moscow's Aerospace Theory of Victory: Western Assumptions and Russian Reality

Dmitry (Dima) Adamsky

DISTRIBUTION STATEMENT A. Approved for public release: distribution unlimited.

Cleared for public release 


\begin{abstract}
This CNA occasional paper explores the defense and offense elements of Russian aerospace operations, addressing three widespread Western assumptions about Russia's approach and theory of victory. Russian air defense operations are a combination of offensive strike and defensive actions, instead of purely defensive as some in the West believe. The commonly used term "anti-access/area denial (A2AD)" is a misnomer in the context of Russian thinking on aerospace operations, and it conjures an inaccurate perception of Russian thinking on this subject. Furthermore, the popular Western belief that Russian operations are driven by a fait accompli strategy, has profound empirical problems. The operational concepts that would enable such a strategy cannot be supported by present-day available capabilities.

Dmitry (Dima) Adamsky is Professor at the School of Government, Diplomacy and Strategy at the IDC Herzliya University, Israel. He is a visiting professor at the Center of Eastern European Studies of the University of Zurich, Switzerland, and at the Faculty of Politics and Diplomacy at the Vytautas Magnus University, Lithuania. He is the author of The Culture of Military Innovation: The Impact of Cultural Factors on the Revolution in Military Affairs in Russia, the US, and Israel (Stanford UP, 2010). His last book Russian Nuclear Orthodoxy: Religion, Politics, and Strategy (Stanford UP, 2019) won the 2020 ISA prize for the best work in the category of Religion and International Relations.
\end{abstract}

This report is part of a series generously funded by a grant from the Carnegie Corporation of New York.

CNA's Occasional Paper series is published by CNA, but the opinions expressed are those of the author(s) and do not necessarily reflect the views of CNA or the Department of the Navy.

\title{
Distribution
}

DISTRIBUTION STATEMENT A. Approved for public release: distribution unlimited.

$2 / 25 / 2021$

This work was performed under Specific Authority Contract No. G-19-56503.

Cover image credit: "Key episodes of Tsentr 2019 exercises at Ashuluk, Donguz and Liaur training grounds," Ministry of Defence of the Russian Federation, http://eng.mil.ru/en/multimedia/photo/gallery.htm?id=69319@ cmsPhotoGallery.

\section{Approved by:}

February 2021

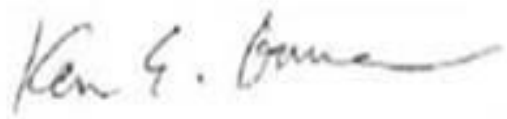
Ken E. Gause, Research Program Director Adversary Analytics Program Strategy, Policy, Plans, and Programs Division

Request additional copies of this document through inquiries@cna.org. 


\section{Executive Summary}

This memo seeks to refute assumptions that are widespread among Western experts about the current Russian approach to aerospace operations and its strategic implications, and to offer alternative interpretations.

First, this report argues, that contrary to the Western claim, the Russian theory and practice of aerospace defense have not been based on defense systems only, but have been a harmonic mixture of offensive (strike) and defensive activities. Moreover, the Russian aerospace operation will probably have not only to lean on defense-offense mix, but also to be preemptive in order to succeed.

Second, this report claims, that in contrast to the Western misnomer "anti-access/area denial," the proper professional term to describe the Russian theory of victory against an aerospace attack on the global and regional levels is Strategic Operation for Repelling Aerospace Aggression-an operational endeavor that encapsulates the abovementioned strike-defense dialectic.

Finally, contrary to the assertion by many Western analysts that a fait accompli strategy is driving Russian operations, this report argues, that there is apparently little space for the political-military leadership to consider this option. The issue is not even the lack of strategic intentions, which are indeed apparently absent; rather, it is insufficient capabilities. If, however, such an unlikely gambit materializes, it is more likely to be the result of hasty overreaction and inadvertent escalation than to be a preplanned move driven by the geopolitical assertiveness that many Russia watchers in the West have been attributing to Moscow.

An additional insight arises from the research. The case under scrutiny reveals that Russian reforms in the aerospace sphere often have been suboptimal, self-damaging, and irrational, because of such nonstrategic factors as the ambitions of the senior military leaders and parochial institutional interests that drove most of the transformations. Consequently, one can grasp the Russian theory of victory in aerospace defense-and in general, any other Russian military modernization and innovation-only in the context of intraservice and interservice competitions. 
This page is intentionally left blank.

CNA Occasional Paper | ii 


\section{Contents}

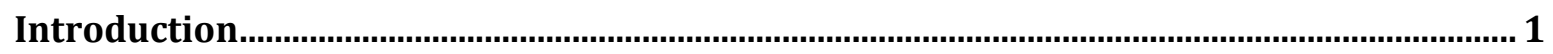

Offensive Component in the Russian Air Defense Tradition..................................................... 3

Offense (strike)-defense dialectics in the Soviet perception of AD ............................................. 3

Strategic operation: an embodiment of the offensive-defensive dialectic ................................ 4

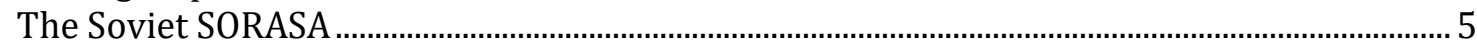

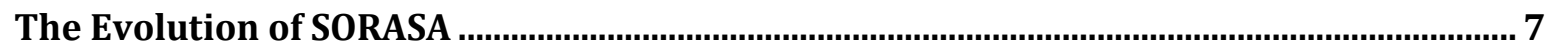

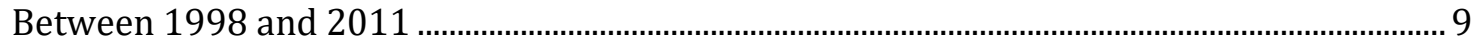

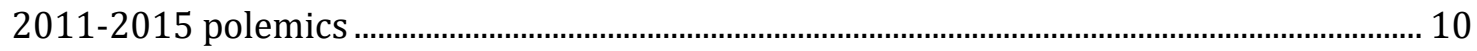

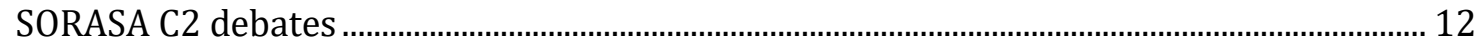

SORASA Deficiencies and Fait Accompli Aspirations.......................................................15

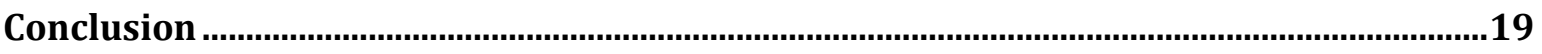

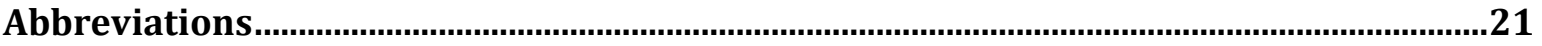

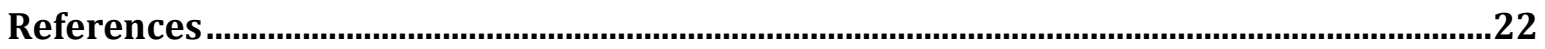


This page is intentionally left blank. 


\section{Introduction}

This monograph wrestles with three assumptions, which are widespread among the expert communities in the West, and which have underlined the US perception of the Russian aerospace theory of victory. The first assumption is that the anti-access/area denial conceptthe Western euphemism for Russian air-defense capabilities-dominates Moscow's military strategy. The second is that this concept is based on defensive weapons systems. The third is that it emboldens the Kremlin to consider a strategy of "fait accompli land grabs"-i.e., opportunistic regional aggression against US allies, mainly in Europe. This monograph argues that these Western articles of conventional wisdom about Russian aerospace power and its political implications are flawed.

This report offers alternative interpretations. First, it argues that historically the Soviet and Russian theory and practice of the air defense (AD) mission have not been based on defensive systems only, as some in the West assume, but have encapsulated a mixture of offensive and defensive capabilities. Second, this report claims that "anti-access/area denial" is a misnomer when it comes to defining the Russian theory of victory against an aerospace attack. To represent the host of activities which Western experts group under the "anti-access/area denial" rubric, and to fill in the missing parts in the Western perception of these activities, this monograph suggests employing the indigenous Russian term "Strategic Operation for Repelling Aerospace Aggression" (SORASA). Finally, this report argues that in contrast to Western estimates, as of this writing, Russian sources assess the capabilities that should enable SORASA's implementation and the overall correlation of forces in the aerospace sphere, as unfavorable. This in itself suggests that the Kremlin is likely to be disinclined to employ the geopolitical course of "fait accompli land grabs."

The report unpacks these arguments in three steps. The first section describes the traditional presence of the strike (offensive) component in the Soviet approach to AD in general, and in SORASA specifically; the second section describes the impact of organizational factors, including the intraservice and interservice competitions over SORASA, and the transformation of services enabling this strategic operation in the post-Soviet era; and the third section describes the Russian estimate of the current deficiencies in the capabilities enabling SORASA and the implications of these flaws for Moscow's strategic aspirations. The conclusion summarizes the findings and offers lessons for future efforts to diagnose Russian strategic behavior, operational activities, and military innovations. 
A methodological note is due. The discussion below, which unpacks these arguments, is based on a specific analytical premise: it is impossible to grasp the evolution of the air (aerospace) defense mission in the Soviet and then the Russian military if the doctrinal thinking and modernization trends are divorced from the impact of organizational-bureaucratic factors. The latter usually have been driven by institutional parochialism, personal ambitions of the political and military leaders, and various interservice and intraservice competitions. The report seeks to demonstrate the confluence of strategic and nonstrategic considerations and their impact on the conceptual and organizational history and current state of the Russian aerospace theory of victory and its implications. 


\section{Offensive Component in the Russian Air Defense Tradition}

Some in the West presume that fighter aviation (IA, istrebitel'naia aviatsiia) troops, and other strike (offensive) components of the Russian military, are entities unrelated to the air defense (AD) mission. They therefore perceive the latter as an activity based on defensive systems. ${ }^{1} \mathrm{~A}$ greater historical and conceptual oversight is difficult to imagine. In Russia, decoupling IA and other offensive elements from the aerospace defense (ASD) is wrong.

\section{Offense (strike)-defense dialectics in the Soviet perception of AD}

The premise regarding the need for an offensive-defensive mix has characterized the Soviet approach since the establishment of the AD Troops (PVO). Since the interwar period, the strike component epitomized by the IA, and by capabilities pertaining to other troops, has been part of the AD mission. Moreover, during some episodes in Soviet history, the role of the strike component was so significant that the IA, the strike element, succeeded, albeit temporarily, in subordinating the whole AD mission to itself and bringing in PVO troops as a sub-element under the command of the Air Force. ${ }^{2}$ Due to this ever-present strike-defense dialectic within the AD mission and the service entrusted with executing it, elements within the PVO have traditionally engaged in two competitions: the first, over the conceptual-organizational leadership of the AD mission, has been between the IA, anti-air artillery (A3), and, from the early 1950s, surface-to-air missile (SAM) lobbies. This contest between the strike (IA) and defense (A3 and SAM) elements remained unresolved until the mid-1960s. Only when the strike element repeatedly demonstrated operational deficiencies was the contest resolved in favor of the missile lobby (which by then had defeated the A3 in the battle for primacy within

\footnotetext{
${ }^{1}$ For example, see discussion in Michael Kofman, "Russian A2/AD: is not overrated, just poorly understood," Russian Military Analysis Blog.

2 When Stalin established the PVO service, the similar mix of "strategic offense" (nuclear and missile projects) and "strategic defense" (national air defense project) branded his thinking. Dmitry (Dima) Adamsky, "The Art of Net Assessment and Uncovering Foreign Military Innovations: Learning from Andrew Marshall's Legacy," Journal of Strategic Studies 43, no. 5 (2020).
} 
the defense element). Both in Vietnam and over the USSR the missile component of the PVO demonstrated a higher effectiveness. ${ }^{3}$

The second competition, over the command and control (C2) authority for the AD mission and areas of responsibility (AoRs), has been between the commanders of the PVO and those of the military districts (MDs). The latter, who had at their disposal strike capabilities that organizationally have not been part of the PVO but are relevant to its mission-i.e., the units of missile and artillery troops (RViA) and the IA-sought to utilize them for the needs of the general-purpose forces under their command. The PVO troops have repeatedly sought to subordinate these elements (at least the defensive ones) directly to themselves. ${ }^{4}$ Despite endless intraservice and interservice competitions, the IA continued to be responsible for the strike element within the PVO, albeit in confusing subordination schemes, and RViA units have been allocated to the PVO mission in an ad hoc manner. The role of missile capabilities, which are subordinated to the commanders of the MDs but assigned to the strike responsibility of the AD missions, has been steadily growing.

\section{Strategic operation: an embodiment of the offensive-defensive dialectic}

Historically, aerospace attack (VKN, Vozdushno-kosmicheskoe napadenie) has been among the most acute military challenges in Moscow's threat perception. Towards the late 1970s, the Soviet General Staff (GS) assumed that an aerospace attack on a strategic scale had become capable of attaining the aims of war by itself. The quest for an adequate strategic countermeasure prompted it to formulate and experiment with the concept of Strategic Operation for Repelling Aero-Space Attack (SORASA) — the pinnacle of the AD theory of victory. ${ }^{5}$ Strategic Operation (SO), a brainchild of Soviet-Russian military thought of the post-civil war period that has been evolving ever since, is a term for combat activities at the highest level of war in a given theater of operations. For the Soviet-Russian military brass, it is a lens through which they design, plan, and execute combined arms operations, and a mechanism that mediates between the political objectives of war and a host of missions entrusted to the

\footnotetext{
${ }^{3}$ Khrushchev's fascination with missile capabilities also prompted his support of the SAM lobby.

${ }^{4}$ Adamsky, "Learning from Andrew Marshall's Legacy."

${ }^{5}$ V.A. Zolotarev, Istoriia Voennoi Strategii Rossii, (Moscow: Kuchkovo Pole, 2000), pp. 467, 469. Also see: Iurii Krinitskii, "Ob'ektivnaia real'nost' nashego vremeni," Vozdushno-Kosmicheskii Rubezh (Aug. 22, 2017).
} 
military. As the highest gradation of military art, it is a responsibility of the supreme echelonsthe GS and commanders of the MDs. As a rule, the Soviet-Russian lexicon has preserved this term to conceptualize its own, not adversarial, military art. ${ }^{6}$

Thus, SORASA, rather than the "anti-access/area denial" misnomer, is the proper term to describe the Soviet (and then Russian) theory of victory against aerospace attack on the globalstrategic and regional-operational levels. SORASA matured into a separate type within the system of SOs codified in the Soviet and then Russian military doctrine. As of this writing, in addition to SORASA, the current Russian SOs comprise the following: Strategic Aerospace Operation, SO for the Destruction of Critically Important Targets, Strategic Nuclear Forces Operation, SO in a Continental Theater of Military Operations, and SO in an Oceanic Theater of Military Operations. Apparently, at least in theory, the GS can wage several SOs at once, or merge them ad hoc according to the changing circumstances, correlation of forces, and political guidance. ${ }^{7}$ Any SO, and SORASA in particular, implies amalgamation under one command of defensive, offensive, and counteroffensive forms of combat, comprising forces from all the services and corps of the military. ${ }^{8}$

\section{The Soviet SORASA}

Moreover, the creators of SORASA assumed that repelling aerospace aggression would be impossible even if all Soviet AD capabilities were activated jointly to destroy the enemy's bombers, ballistic missiles, and cruise missiles in flight. To thwart the menace, their theory of victory demanded involving the offensive capabilities of other services, in order to destroy the means of attack not only in flight, but also on the ground, at sea, and in space, as well as the command, control, communications, and intelligence (C3I) systems supporting them. SORASA thus became the "sum (savokupnost') of coordinated and interrelated operations of all services and corps under one senior strategic authority." 9

The Soviet SORASA rested on the following postulates: First, there must be systemic integration of defensive elements and offensive (strike) components. Second, the strike component should encapsulate the capabilities of services within and beyond State (i.e.

\footnotetext{
${ }^{6}$ Zolotarev, Istoriia Voennoi Strategii Rossii.

7 Ibid.; Michael Kofman, Anya Fink, and Jeffrey Edmonds, Russian Strategy for Escalation Management, CNA, DRM-2019-U-022455-1Rev, 2020. Dave Johnson, Russia's Conventional Precision Strike Capabilities, Regional Crises and Nuclear Thresholds, (Livermore, CA: CGSR, 2018), pp. 30-36.

${ }^{8}$ Russian military dictionaries.

${ }^{9}$ Zolotarev, Istoriia Voennoi Strategii Rossii, pp. 467, 469. Uirii Krinitsky, "Vozdushno-Kosmicheskii Teatr Voennykh Deistvii," VPK 5 (Feb. 6, 2013); Krinitskii, “Ob'ektivnaia real'nost' nashego vremeni.”
} 
covering strategic rear of state territory and not the territory of the MDs) Air Defense Service (PVO Strany) -IA, RViA, radio-electronic warfare (REB, radiolektronnaia bor'ba), nuclear- and nonnuclear-armed long-range aviation (DA, dal'niaia aviatsiia), maritime aviation, and the missile capabilities of the navy and strategic nuclear forces (RVSN, raketnye voiska strategicheskogo naznacheniia). These assets would strike the adversary's missile and air bases, C3I centers, and navigation systems, as well as its missile-carrying submarines and air carrier groups. The strikes would be conducted according to the plans of the SO of the nuclear forces and the SO on continental and ocean theaters of military operations (TVDs), but integrated within the unified plan of SORASA. ${ }^{10}$ Third, the scope of SORASA should depend on the level of the threat, ranging from a global aerospace attack to one conducted on a regional TVD.

In terms of authority, the Soviet theory designated the General Staff (GS) as the operator of global SORASA, and the MD commander (commander of strategic direction) as the operator of SORASA on the TVD. In both cases, SORASA delegated the "decisive" C2 role to the PVO commander.11 During the last Soviet decade, when MDs were integrated into the main commands/strategic directions-Western, Southwestern, Southern and Far Eastern-all types of SO on the TVD (offensive, counteroffensive, and defensive) were subordinated to them as well. The GS was responsible for the planning and execution of global strategic actions, SO of the Strategic Nuclear Forces, and SORASA. ${ }^{2}$ In 1987, the theory of SORASA, in its accomplished form, was nominated for a prestigious Soviet scientific award. ${ }^{13}$

10 Zolotarev, Istoriia Voennoi Strategii Rossii, pp. 468-469. On the offense-defense integration in the original SORASA, also see: A.V. Belomytsev, M.G. Valeev, and N.L. Romas', “O forme bor'by s vozdushnokosmicheskim protivnikom," VM 5 (May 2014): p. 3; Vladimir Barvinenko, "I vnov' ostryi zud reformatorstva," VKP 38 (Oct. 2, 2013).

11 Zolotarev, Istoriia Voennoi Strategii Rossii, pp. 468, 495.

12 Ibid., p. 478. Also see: Anatolii Khiupenen and Sergei Pokladov, "Kto organizuet bor'bu na novom TVD," VPK 19 (Dec. 2011).

13 V.N. Liaporov, “Kuznitse Voennykh Kadrov VKS - 60 let,” VM, no. 1 (2017): pp. 2-8. 


\section{The Evolution of SORASA}

The contemporary Russian theory of victory in aerospace, of which the Soviet SORASA was a precursor, demonstrates remarkable historical continuity. Following the Soviet collapse, the Russian GS saw "the center of gravity of the current character of war moving to the aerospace sphere." 14 Consequently, the Russian military inherited the Soviet SORASA as a doctrinal frame of reference for repelling this menace. Despite several reincarnations of the concept and the services executing it, the Russian military preserved and continued to develop the original SORASA's postulates. ${ }^{15}$ The Russian military sees repelling aerospace aggression as a holistic endeavor encapsulating all the strike and defensive capabilities aimed against all means of aerospace aggression (ASA), in their bases, in flight, and over the TVD. ${ }^{16}$ Russian experts attribute the offensive element of SORASA to the same components as in the Soviet era: IA, ${ }^{17}$ DA, ${ }^{18}$ navy vessels, maritime and regular aviation carrying cruise missiles, ${ }^{19}$ REB, ${ }^{20} \mathrm{RViA}^{21}$

\footnotetext{
${ }^{14}$ S.G. Chekinov, V.I. Makarov, and V.V. Kochergin, "Zavoevanie I uderzhanie gospodstva v vozdukhe," $V M$, no. 2 (Feb. 2017): p. 60.

15 O.N. Ostapenko, S.V. Baushev, and I.V. Morozov, Informatsionno-Kosmicheskoe Obespechenie Gruppirovok Voisk (Sil) VS RF, (St. Petersburg: Izd. Liubavich, 2012), pp. 139-140.

16 A.D. Gavrilov, "Problemy bor'by s sovremennymi sredstvami vozdushnogo napadeniia," zvestiia Rossiiskoi akademii raketnykh i artilleriiskikh nauk, no. 3 (2018).

17 Vladimir Barvinenko, “Osobaia rol' IA v VKO," VPK, no. 14 (Apr. 16, 2014); Ostapenko, Baushev, and Morozov, Informatsionno-Kosmicheskoe Obespechenie Gruppirovok Voisk (Sil) VS RF, p. 143. Belomytsev, Valeev, and Romas', “O forme bor'by s vozdushno-kosmicheskim protivnikom," pp. 7, 9.

${ }^{18}$ Belomytsev, Valeev, and Romas', “O forme bor'by s vozdushno-kosmicheskim protivnikom,” pp. 7-9; Ostapenko, Baushev, and Morozov, Informatsionno-Kosmicheskoe Obespechenie Gruppirovok Voisk (Sil) VS RF, pp. 139-140.

19 Belomytsev, Valeev, and Romas', “O forme bor'by s vozdushno-kosmicheskim protivnikom,” p. 9; Barvinenko, "I vnov' ostryi zud reformatorstva."

${ }^{20}$ Chekinov, Makarov, and Kochergin, "Zavoevanie I uderzhanie gospodstva v vozdukhe.”; V.A. Subbotin and A.M. Shavelkin, “Edinaia sistema PVO - kakoi ei byt'?," VM, no. 10 (Oct. 2010): p. 6.

${ }^{21}$ Gavrilov, "Problemy bor'by s sovremennymi sredstvami vozdushnogo napadeniia."; Subbotin and Shavelkin, "Edinaia sistema PVO - kakoi ei byt'?," p. 76; Barvinenko, "I vnov' ostryi zud reformatorstva."
} 
airborne troops (VDV),22 and the nuclear triad.23 The novelties are cyber capabilities, sabotagediversion groups, and special operations forces, ${ }^{24}$ and the targeting logic mimics the Soviet version. 25

However, reforms, competition among the services, and deficiencies in capabilities have raised obstacles to executing the ideal type of SORASA. As is often the case in bureaucratic politics, organizational competition has been interwoven with the conceptual debates, on the principle that where one stands [conceptually] depends on where one sits [organizationally]. Towards and following the establishment in 2015 of the service associated with SORASA-the Aerospace Forces (VKS) -institutional-doctrinal rivalries peaked. Many of the reforms have been suboptimal, self-damaging, and irrational. Russian experts claim that "personal ambitions" of the senior military leaders and institutional interests of the services drove the majority of the PVO reforms (about two dozen) from World War II up until 2015.26 The parochialism of the post-Soviet reforms, the narrow-mindedness of some of their authors, the efforts to please the leadership, and the promotion of organizational ambitions at the expense of other services often repeated the pathologies of the Soviet PVO reorganizations. ${ }^{27}$ As was the case back then, a major downsizing of the military and the lack of a coherent vision produced a favorable atmosphere for the intraservice and interservice contests. ${ }^{28}$ Since many organizational-conceptual issues have remained unresolved, professional debates have been ongoing. What follows is a brief history of the institutional-conceptual milestones related to SORASA and the services enabling it.

\footnotetext{
22 Makhmut Gareev, "Sozdanie VKO - Vazhneishaia Gosudarstvennaia zadachia," 3 (2011): p. 9.

${ }^{23}$ Krinitsky, "Vozdushno-Kosmicheskii Teatr Voennykh Deistvii."; Subbotin and Shavelkin, "Edinaia sistema PVO - kakoi ei byt'?," p. 76.

24 Gavrilov, "Problemy bor'by s sovremennymi sredstvami vozdushnogo napadeniia," p. 15-20; Ostapenko, Baushev, and Morozov, Informatsionno-Kosmicheskoe Obespechenie Gruppirovok Voisk (Sil) $V S R F$, p. 216.

${ }^{25}$ Ostapenko, Baushev, and Morozov, Informatsionno-Kosmicheskoe Obespechenie Gruppirovok Voisk (Sil) VS RF, p. 121.

${ }^{26}$ A.A. Sinikov, "O structure VKS oborony strany," VM, no. 7 (July 2017): p. 93; I.V. Erokhin, Vozdushnokismicheskaia sfera I vooruzhennaia bor'ba v nei, (Tver': VA VKO, 2008). Adamsky, "Learning from Andrew Marshall's Legacy."

27 Barvinenko, "I vnov' ostryi zud reformatorstva."; Adamsky, "Learning from Andrew Marshall's Legacy."

${ }^{28}$ Adamsky, "Learning from Andrew Marshall's Legacy."; Krinitsky, "Vozdushno-Kosmicheskii Teatr Voennykh Deistvii."
} 


\section{Between 1998 and 2011}

Against the backdrop of the budget deficit and the downsizing of the Russian military, the PVO Strany has been shrinking since the Soviet collapse. The 1998 reform dismantled the troops as an independent service, and distributed them among other services. ${ }^{29}$ In 2011 the remaining troops were named the Aerospace Defense (VKO) - an entity established to express the political-military perception of the aerospace threat. Because this aerospace threat was a reincarnation of earlier threats-first, of the strategic bombing menace from the Nazi Wehrmacht during World War II, and then of the US and NATO bomber-missile threat-many saw the VKO as a re-embodiment of the PVO Strany. ${ }^{30}$ From the outset, the VKO was a confusing entity. On the one hand, the new troops perceived themselves as an initial step towards a revival of the PVO Strany, albeit in a downgraded version, but with possible progression back to the golden era, when the PVO Strany had been one of the five services (unlike the VKO, which was subordinated to a majority of the AD units, the Missile Defense [PRO, protivoraketnaia oborona] and space troops). ${ }^{31}$ The VKO seniors invented a new title-“Operational-Strategic Command of the Aerospace Defense" - that was meant to communicate that the VKO is an independent entity that does not necessarily correspond with the AoR of the MDs.

In reality, several deficiencies plagued the VKO, putting into question its ability to repel ASA. First, doctrinally, the role of the VKO in the system of SO was undefined. While the Soviet PVO Strany had its own force employment plans to execute SORASA, the VKO lacked any such plans. ${ }^{32}$ Second, the VKO had nominal-technical responsibility but not actual command authority over most of its forces. ${ }^{33}$ Its assets were under five organs: the commander of the VKO and four commanders of MDs. ${ }^{34}$ The biggest issue was coordination, or lack thereof,

\footnotetext{
${ }^{29}$ The AF received the MD forces (PRO); the RVSN received the space forces; and the PVO and VVS armies were divided among the MDs. Krinitsky, "Vozdushno-Kosmicheskii Teatr Voennykh Deistvii."

${ }^{30}$ Adamsky, "Learning from Andrew Marshall's Legacy."

${ }^{31}$ Belomytsev, Valeev, and Romas', “O forme bor'by s vozdushno-kosmicheskim protivnikom,” pp. 3-9.

32 Andrei Goncharov, "V perspective - protivokosmicheskaia operatsiia," VKO (June 15, 2014). Since the early 2000s, for the sake of SORASA, the plan was to employ "differently-subordinated" (raznopodchenennye) forces and $\mathrm{AD}$ elements were incorporated in the actions of offensive (strike) services. Belomytsev, Valeev, and Romas', “O forme bor'by s vozdushno-kosmicheskim protivnikom,” pp. $2-4$.

${ }^{33}$ Belomytsev, Valeev, and Romas', “O forme bor'by s vozdushno-kosmicheskim protivnikom,” pp. 2-4.

${ }^{34}$ Barvinenko, "I vnov' ostryi zud reformatorstva," pp. 2-4; Belomytsev, Valeev, and Romas', “O forme bor'by s vozdushno-kosmicheskim protivnikom."
} 
between the forces of the VKO and the PVO forces subordinated to commanders of MDs. ${ }^{35}$ Under this "multi-power" (mnogovlastie) arrangement, there was "unity of neither operational design nor operational planning, no joint contour of command of the VKO forces, and no unified combat responsibility." 36 Finally, the VKO received just those assets that could destroy targets in flight-defensive systems only. ${ }^{37}$ These insufficiencies made it impossible for the VKO to execute SORASA, which was planned in conjunction with the posture, AoR, and capabilities of the PVO Strany at its bureaucratic best. 38

A vague definition of authority, responsibility, and order of battle of the VKO, ${ }^{39}$ and a feeling that this was just the initial and not the final round of reorganization, left ample space for organizational struggles aimed at appropriating the new service or parts of it. ${ }^{40}$ Moreover, between 2011 and 2015 the senior brass permitted, if not actually stimulated, polemics to better inform the prospective reorganization. The polemics discussed below gave shape to the current posture of forces executing SORASA.

\section{1-2015 polemics}

Between 2011 (establishment of the VKO) and 2015 (establishment of the VKS), there were major discussions among military commanders, theoreticians, and defense officials about the procedures and C2 architecture related to SORASA. By that time, across the Russian strategic community there was general agreement that neither offense nor defense by itself is sufficient to neutralize a menace and that the two should be merged. ${ }^{41}$ This "merging" was elegant only in theory; in reality there were several major disagreements: one on the scale of independence of the strike and defense segments; 42 one on the involvement of strike segments from other services; and one on the C2 merging them. Two competing schools of thought on the

\footnotetext{
${ }^{35}$ Barvinenko, "I vnov' ostryi zud reformatorstva."

${ }^{36}$ Belomytsev, Valeev, and Romas', "O forme bor'by s vozdushno-kosmicheskim protivnikom,” pp. 2-4.

37 Barvinenko, "I vnov' ostryi zud reformatorstva."

${ }^{38}$ Belomytsev, Valeev, and Romas', “O forme bor'by s vozdushno-kosmicheskim protivnikom,” pp. 2-4.

${ }^{39}$ Goncharov, "V perspective - protivokosmicheskaia operatsiia."

${ }^{40}$ Krinitsky, "Vozdushno-Kosmicheskii Teatr Voennykh Deistvii."

${ }^{41}$ Belomytsev, Valeev, and Romas', "O forme bor'by s vozdushno-kosmicheskim protivnikom,” pp. 2-6.

42 As well as coordination within the defense segment itself between the PVO Ground Forces subordinated to MDs vs. the AD forces subordinated to the VKO service.
} 
employment of strike and defense in a "disjointed" ( $v$ obosoblennoi) way or in a "joint" (v edinoi) manner, within SORASA, emerged.43 The conceptual debate cannot be grasped in isolation from its organizational subtext. Each school's theory of victory correlated with the organizational affiliation of its advocates, and promoted their institutional interests. The contest over the offensive-defensive posture reflected the VKO's effort to preserve its status as an independent service, building and employing force and expanding its command autonomy, against the AF's and MDs' efforts to subordinate the SORASA mission, and have the VKO forces execute it under their command.

The "disjointed" school argued that the strike element and defensive component in SORASA should each have its own missions, targets, ISR, and means, and thus execute its tasks independently throughout the operation. This school argued that the "apartness" (obosoblennost') of the VKO employment and strike missions demands minimal interoperability, and that the synergy between the endeavors would emerge. ${ }^{44}$ This claim implied that the destruction of means of ASA on the ground and at sea should occur within independent strike forms of force employment under different command authorities (udarnue formy voennykh desitvii pod rukovodstvom drugikh komandovanii na svoikh TVD). ${ }^{45}$ This call for purely autonomous AD missions had a clear institutional subtext. By disjoining the strike and defensive elements of SORASA, the VKO lobby sought to place under itself all means of PVO, including those subordinated to the MD commanders. In its ultimate form, this claim implied subordinating to the authority of the VKO all defensive assets participating in repulsion of ASA, and fully isolating them from other services and troops, on both the strategic and operational levels. ${ }^{46}$

In contrast, the "joint" school called for the integration of offensive and defensive elements, and saw the VKO's claim of independence as an obstruction to SORASA's realization. ${ }^{47}$ The proponents of the "joint" school justified their claim with the following arguments: First, the massive downsizing of the military had reduced the number of strike and defense assets involved in repelling ASA. Optimal utilization of this diminished force, which would aim at the

\footnotetext{
${ }^{43}$ Belomytsev, Valeev, and Romas', “O forme bor'by s vozdushno-kosmicheskim protivnikom," p. 5. Also see: Vladimir Barvinenko, “Vykhod Odin - V Konsentracii Usilii,” VKO, no. 6 (2015).

${ }^{44}$ ibid.; Krinitsky, "Vozdushno-Kosmicheskii Teatr Voennykh Deistvii."; Belomytsev, Valeev, and Romas', "O forme bor'by s vozdushno-kosmicheskim protivnikom," pp. 2-9.

${ }^{45}$ Barvinenko, "I vnov' ostryi zud reformatorstva." This implied that defense and strike endeavors are separate strategic operations. Krinitsky, "Vozdushno-Kosmicheskii Teatr Voennykh Deistvii."

${ }^{46}$ Barvinenko, "I vnov' ostryi zud reformatorstva."; Barvinenko, "Vykhod Odin."

${ }^{47}$ Barvinenko, "I vnov' ostryi zud reformatorstva."; Barvinenko, "Vykhod Odin."
} 
same time to cover Russian forces and to attack the ASA assets, demanded coordination. Second, the separation of strikes and defense operations would double the number of force employment scenarios and complicate coordinating the destruction of the means of ASA in flight, on the ground, and at sea. Finally, the destruction of enemy aviation over enemy territory is possible only if the offensive element simultaneously suppresses the adversarial $A D$, which demands coordination; otherwise, it is impossible to optimize the use of the Russian AF for three missions: to repel the strikes of the enemy in flight, to conduct strikes on his infrastructure, and to escort Russian DA. 48

\section{SORASA C2 debates}

The "joint-disjointed" polemics were linked to the debate on the meta-operator of SORASA. This discussion reflected the same organizational-conceptual competitions. In general, postSoviet transformations, often driven by efforts to save resources, produced cumbersome C2 verticals. ${ }^{49}$ This was particularly acute in the case of SORASA, which had already been suffering from frequent restructurings ${ }^{50}$ and a suboptimal command setting. As of 2011, most of the VKO $\mathrm{AD}$ assets were subordinated to the MDs, and the VKO AoRs corresponded with those of the MDs, not with the potential aerospace aggression. As during the Soviet era, such a setting was flawed: the adversary has been planning aggression not in keeping with Russian administrative divisions, but according to its own theory of victory. ${ }^{51}$ The competing schools of thought have been promoting different postures to address this issue. Some have called for a division between the administrative and operational functions of the VKO; others have demanded that the VKO be turned into a service, fully owning the force; still others have called for establishing

\footnotetext{
48 Barvinenko, "I vnov' ostryi zud reformatorstva."; Belomytsev, Valeev, and Romas', “O forme bor'by s vozdushno-kosmicheskim protivnikom," pp. 7-8.

${ }^{49}$ R. A. Novikov and Iu. V. Krinitskii, "Organizatsionnaya Struktura Voisk, Vypolnyayushchikh Boevye Zadachi v Vozdushnoi (Vozdushno-Kosmicheskoi) Sfere,", Voennaya Mysl', no. 2 (Feb. 2017): p. 25. During that time, SORASA was even merged with the Strategic Air Offensive Operation into the Strategic Aerospace Operation; Krinitskii, “Ob'ektivnaia real'nost' nashego vremeni."

50 Zolotarev, Istoriia Voennoi Strategii Rossii, pp. 494-495; Novikov and Krinitskii, "Organizatsionnaya Struktura Voisk, Vypolnyayushchikh Boevye Zadachi v Vozdushnoi (Vozdushno-Kosmicheskoi) Sfere,", pp. 23-25.

${ }^{51}$ Iu. V. Krinitskii, "Sovmeschenie vozdushnykh I strategicsheskih napravlenii," VM, no. 10 (2005): pp. 44-48; Krinitskii, "Ob'ektivnaia real'nost' nashego vremeni."
} 
a new, unified service incorporating the offensive and defensive components of the AF and AD, with ad hoc responsibility to coordinate with the strike forces. 52

Others have called for the establishment of the meta-operator of SORASA 53 - not in the form of a service, but as a function in the GS. This would require the concentration of strike and defense efforts from all services (a preference of the "joint school") in the form of a Strategic Aerospace Command (SASC) authorized to orchestrate force employment. ${ }^{54}$ Most officials gravitated towards this view. They imagined it not as a service, but as an organ within the GS which "should command the employment of all forces involved regardless of their affiliation and forms of activity," including the nuclear one. The authors of the initiative recommended that if SASC were not to be established, most of its C2 functions should be entrusted to the VKS. 55

In sum, there are no sources available that indicate categorically how these disputes have been resolved. However, as of this writing, the heated polemics of the first 15 years of the $21^{\text {st }}$ century have abated. The reintroduction of "strategic directions" 56 might imply a unity of command in the hands of the MD commander, who by extension becomes the meta-operator of SORASA on the TVD. Delegating command over the SORASA to the MD commander would be in keeping with the traits of the Russian ground-continental tradition of war. Nominating the commander of the VKS as a meta-operator of SORASA, even in an ad hoc manner, is hypothetically possible, but less likely. If such a setting does materialize, however, it will illustrate significant discontinuity in the Russian strategic and military cultures. Evidence from the Syrian operation suggests that a meta-operator might be a nominee within the Operational Department of the GS or a specially designated commander of the MD. ${ }^{57}$ Also, regardless of

\footnotetext{
${ }^{52}$ Novikov and Krinitskii, "Organizatsionnaya Struktura Voisk, Vypolnyayushchikh Boevye Zadachi v Vozdushnoi (Vozdushno-Kosmicheskoi) Sfere," pp. 25-26; Goncharov, "V perspective protivokosmicheskaia operatsiia."; Andrei Goncharov, "Voina budet vo vsekh sredakh," Voennokosmicheskaia oborona, no. 6 (Dec. 2, 2015).

${ }^{53}$ Gareev, "Sozdanie VKO - Vazhneishaia Gosudarstvennaia zadachia," pp. 6-13; Subbotin and Shavelkin, “Edinaia sistema PVO - kakoi ei byt'?," pp. 69-77.

${ }^{54}$ Barvinenko, "I vnov' ostryi zud reformatorstva."

55 Iurii Anoshko and Vladimir Barvinenko, "Starue problem novogo vida VS," VKO, no. 3 (2015): pp. 2931.
}

56 For an elaboration, see: Novikov and Krinitskii, "Organizatsionnaya Struktura Voisk, Vypolnyayushchikh Boevye Zadachi v Vozdushnoi (Vozdushno-Kosmicheskoi) Sfere,"” p. 23.

${ }^{57}$ One may qualify the grouping of forces in Syria and the operation it has been conducting as equivalent to a temporary Operational-Strategic Command waging a strategic operation on a TVD/Strategic direction. So far, five commanders of the grouping of forces have been commanders of the MDs. All of them are ground forces career officers, although the official title of the combat activities over which they 
these conundrums, Russian sources indicate that a mix of offensive and defensive elements in a struggle for aerospace dominance has been and still is common professional wisdom. 58

commanded has been "the VKS Operation." The Main Operations Directorate of the GS has been planning this operation, which is managed through National Defense Management Center and executed on the ground by a main operator-commander of the grouping of forces, former commander of the MDs. Hypothesizing by extension from the Syrian case, one may parallel this C2 architecture to the one expected during a regional, if not global, SORASA. For the evolution and current strategic C2 architecture and its procedures, see: Greg Whisler, "Strategic Command and Control of the Russian Armed Forces," Journal of Slavic Military Studies 33, no. 2 (2020).

${ }^{58}$ For example, see: Ostapenko, Baushev, and Morozov, Informatsionno-Kosmicheskoe Obespechenie Gruppirovok Voisk (Sil) VS RF, p. 121; V.V. Barvinenko, “O popytkakh revizii polozhenii teorii VKO,” VM, no. 4 (Apr. 2018). 


\section{SORASA Deficiencies and Fait Accompli Aspirations}

Russian experts argue that in contrast to previous transformations, the 2015 reform, which merged the AF and VKO into the VKS, was thought through, and executed after serious scientific discussions and experimentation. In theory, the VKS was aimed at improving aerospace defense and SORASA, via the synergy of offensive and defensive forces, nonexistent in the VKO when it was a separate entity (2011-2014). In reality, however, the VKS inherited from the VKO the same pathologies; 59 thus, as of this writing, the following organizational, operational, and procedural deficiencies have been plaguing the capacity of the Russian military to properly execute the mission of strategic aerospace defense.

First, there is an issue with AoR and C2 procedures. As of 2017, the VKS commanded only the on-duty units of the VKO and AF within the MDs; the modification (podgonka) of the aerospaceto-ground strategic directions remained intact; and most of the AD assets were designated to support forces of the MDs, and not allocated to the repulsion of the missile-aviation salvo. The VKS lacked C2 over the different types of aviation: strike and front (bombordirovachnja I shturmovoaia) aviation was subordinated to the MD commander, and DA to the GS. The procedures of IA employment were unclear: it was subordinated to the MD commander to support ground forces on the TVD but, at the same time, was expected to secure DA conducting its own counterstrike (otvetno-vstrechnye udary) missions; also, the system of electronic warfare of missile attack was not subordinated to the commander of the VKS. 60

Second, the strike component-especially the advanced, long-range precision-guided arsenal-is insufficient to support SORASA missions. The Russian military has been steadily

\footnotetext{
59 Sinikov, "O structure VKS oborony strany," p. 93; Goncharov, "V perspective - protivokosmicheskaia operatsiia.”; Chekinov, Makarov, and Kochergin, "Zavoevanie I uderzhanie gospodstva v vozdukhe,” p. 5.

${ }^{60}$ Novikov and Krinitskii, "Organizatsionnaya Struktura Voisk, Vypolnyayushchikh Boevye Zadachi v Vozdushnoi (Vozdushno-Kosmicheskoi) Sfere,," pp. 26-28. For additional limitations of the EW systems in supporting strategic defense, see: O.Iu. Aksenov, Iu.N. Tretiakov, and E.N. Filin, "Strategicheskie oboronitel'nye sistemy kak factor sderzhivania agressii," VM (2015): pp. 15-21; "Osnovnue printsipy sozdaniia otsenki tekuschego I prognozongo uscherba vazhneishim ob'ektam sistemy strategicheskogo sderzhivaniia," VM, no. 6 (2015): pp. 68-74. Most of these deficiencies replicate and are a direct extension of the PVO Strany weaknesses during the Cold War. See Adamsky, "Learning from Andrew Marshall's Legacy."
} 
embracing the precision-strike regime; ${ }^{61}$ however, according to Russian and Western estimates, the relatively low numbers of these capabilities together with the ongoing deployment of the US BMD, downgrade the ability to inflict desired ("assigned") damage in offensive (strike) operations, and to dominate escalation.62 The GS's experts have argued that the weakness also derives from the insufficient role given to the strike components within the offensive-defensive mix and insufficient elaboration on this issue in the doctrinal-planning documents. To them, one of the main characteristics of maintaining aerospace superiority is periodic change in the role of missile-air strikes on the surface targets and destruction of the means of attack in flight. According to them, when repelling aerospace aggression, employment of the strike forces only after the defensive endeavor (apparently still the case) is mistaken, "archaic military thinking." 63

Finally, the view of the organ that would merge strike and defensive components and manage them on the strategic directions is under-elaborated.64 Apparently, the reform did not introduce SASC, and left the C2 problem unresolved. The VKS acquired force buildup responsibility but lacked the authority to employ in SORASA all the AD and strike components from the other services.65 Discussing the C2 issue in 2017, experts of the GS called for "strict command centralization"-i.e., "a unity of action for strike, defense and maintenance forces under joint command"-implying that the general command authority would stem from the GS and MD, while the actual employment of forces would be conducted by commanders of the VKS armies.66 However, as of 2019, the meta-operator of SORASA was unclear. Authors analyzing the evolution of the VKS development in VM did not mention a separate organ of strategic command, and attributed most of the organizational, force buildup, and employment

${ }^{61}$ Roger McDermott and Tor Bukkvol, "Tools of Future Wars," The Journal of Slavic Military Studies 31, no. 2 (2018).

${ }^{62}$ For example see: Clint Reach, Vikram Kilambi, and Mark Cozad, Russian Assessments and Applications of the Correlation of Forces and Means, RAND, 2020, pp. 122-123, 126; Konstantin Sivkov, "Nebesnye bastiony," VPK (Feb. 18, 2019).

${ }^{63}$ Chekinov, Makarov, and Kochergin, "Zavoevanie I uderzhanie gospodstva v vozdukhe," pp. 59-65.Also see: A.V. Rudnenko, O.V. Milenin, and A.V.Bykardov, "K voprosu o gospodstve v vozdushnokosmicheskom prostranstve," VM, no. 3 (Mar. 2017): p. 85.

${ }^{64}$ M.G. Valeev, E.N. Akhmerov, and D.E. Akhmerov, "Osnovnye podkhody k obosnovaniiu gruppirovok voisk PVO na strategicsheskih napravleniiakh," VM, no. 9 (Sept. 2015). Also see: Krinitskii, "Ob'ektivnaia real'nost' nashego vremeni."

${ }^{65}$ Anoshko and Barvinenko, "Starue problem novogo vida VS," pp. 27-34.

${ }^{66}$ Chekinov, Makarov, and Kochergin, “Zavoevanie I uderzhanie gospodstva v vozdukhe," pp. 61-62. 
authorities to the VKS. However, they neither explicitly defined it as meta-operator nor discussed its wartime relations with the MD commanders and the GS.67 Other commentaries have promoted the MD commanders as the authority merging strike and defensive forces in an SO on the TDV. ${ }^{68}$ Since the commanders of the MDs (joint operational-strategic commands) are likely to become commanders on the TVD in wartime, ${ }^{69}$ this setting apparently allocates the command of strategic operations on the TVD, and possibly of SORASA, to the commander of the Military District/Strategic Director/Unified Operational-Strategic Command, ${ }^{70}$ assuming that regional and functional TVDs will be treated in a similar manner. ${ }^{71}$

In sum, due to these deficiencies, Russian experts have been questioning the capacity of strategic AD capabilities to thwart a conventional precision aerospace attack on several axes. ${ }^{72}$ In 2017 specialists of the Center of Strategic Research of the GS, echoed by the VKS professionals, ${ }^{73}$ asserted that "in the aerospace sphere, the quantitative-qualitative correlation of forces" is not in Russia's favor. In their estimation, under such an unfavorable correlation of forces, even if the most significant effort of the Russian military to disrupt (sorvat') and repel (otrazit') an ASA achieves satisfactory results, the mission of "conquering aerospace dominance" and "strategic initiative" is beyond the reach of Russian capacity circa 2017.74 According to another estimation, against the massive Prompt Global Strike, Russia can deploy "parochial and systemically unconnected (sistemno ne vzaimosviazannykh) activities, executed

${ }^{67}$ S.N. Borisko and S.A. Goremykin, “Analiz Sostoianiia VKS Rossii,” VM, no. 1 (Jan. 2019).

${ }^{68}$ A.P. Korabel'nikov, "Sovremennye sposoby vozdushno-kosmicheskoi, protivovozdushnoi oborony obiektov," VM, no. 1 (Jan. 2019): pp. 38-49.

69 Johnson, Russia's Conventional Precision Strike Capabilities, p. 73.

70 Vladimir Ostankov, “Voiny Buduschego Nachinajutsia Segodnia,” VPK, no. 40 (Oct. 15, 2019).

${ }^{71}$ Michael Kofman and Anya Loukianova Fink, "Escalation Management and Nuclear Employemnt in Russian Miltary Strategy," War on The Rocks.

${ }^{72}$ Anatolii Khramchikhin, "Voiska mirnogo neba," Nezavisimoe voennoe obozrenie (Nov. 22, 2018); Aleksandr Khramchikhin, Rethinking the Danger of Escalation: The Russia-NATO Military Balance, Carnegie Endowment for International Peace, Jan. 25, 2018; Goncharov, "Voina budet vo vsekh sredakh."; ibid.

73 Rudnenko, Milenin, and A.V.Bykardov, "K voprosu o gospodstve v vozdushno-kosmicheskom prostranstve," pp. 84-93.

${ }^{74}$ Chekinov, Makarov, and Kochergin, "Zavoevanie I uderzhanie gospodstva v vozdukhe," pp. 2-8; Rudnenko, Milenin, and A.V.Bykardov, "K voprosu o gospodstve $\mathrm{v}$ vozdushno-kosmicheskom prostranstve," p. 85. 
by functionally disjointed organizational structures subordinated to different command authorities (funktsional'no razroznenymi I raznopodchinennymi strukturami)."75

As of 2019, it was unclear to what extent the VKS has addressed these deficiencies. ${ }^{76}$ As Kofman and Lukyanova Fink argue, after analyzing a trove of Russian sources up to 2020, degrading ASA - "mitigating its effects-is possible for the Russian military, but denying it is not."77 Moreover, the Russian military brass is likely to assume that, as happened during the Cold War, the adversary might turn the above flaws, which underlie the Russian capacity to execute the ideal type of SORASA, into strategic-operational vulnerabilities and then exploit them to coerce, if not defeat, the Russian military during an aerospace attack. Against the backdrop of the questionable combat potential of the Russian military in its current shape to repulse effectively a massive NATO aerospace campaign, the military brass estimates the chances of successful execution of SORASA, if not augmented by nuclear capabilities, as low. As long as SORASA deficiencies have not been fixed, the Russian military is likely to opt for non-strategic nuclear weapons in the initial period of war. ${ }^{78}$

Within the Russian strategic community, the apparent awareness of these insufficiencies in the realm of military capabilities, and the limits of power which they produce, is likely to project on the realm of geopolitical intentions. Presumably, the Russian political leadership shares these insights of the military brass about the correlation of forces in the aerospace sphere. This conventional wisdom, in turn, is likely to predispose the leadership towards a defensivereserved rather than assertive-offensive modus operandi, and to curtail rather than embolden the geopolitical assertiveness; thus, it would probably disincline rather than predispose Moscow to opt for a fait accompli strategy. The Kremlin's strategic intentions aside, ${ }^{79}$ solely the analysis of military capabilities suggests a lack of confidence to plan for "sanctuarization" gambits.

\footnotetext{
${ }^{75}$ Novikov and Krinitskii, "Organizatsionnaya Struktura Voisk, Vypolnyayushchikh Boevye Zadachi v Vozdushnoi (Vozdushno-Kosmicheskoi) Sfere,," p. 28.

76 O.V. Milenin and N.V. Golovzin, “Rozhdennaia v gody VOV,” VM, no. 2 (Feb. 2019).

77 Kofman and Fink, "Escalation Management and Nuclear Employemnt in Russian Miltary Strategy." Also see: Kofman, Fink, and Edmonds, Russian Strategy for Escalation Management.

${ }^{78}$ For the Russian estimates of unfavorable correlation of forces in SORASA and for transition to NSWN, see: Reach, Kilambi, and Cozad, Russian Assessments and Applications of the Correlation of Forces and Means, pp. 125-126; Kofman, Fink, and Edmonds, Russian Strategy for Escalation Management; Johnson, Russia's Conventional Precision Strike Capabilities, pp. 73-74, 95; Kofman and Fink, "Escalation Management and Nuclear Employemnt in Russian Miltary Strategy."

79 Michael Kofman, "Assessing Russian Fait accompli strategy," Russian Analytical Digest 259 (Nov. 2020): pp. 9-12.
} 


\section{Conclusion}

This memo has sought to refute assumptions that are widespread among Western experts about the current Russian approach to aerospace operations and its strategic implications, and to offer alternative interpretations.

First, contrary to the Western claim, the Russian theory and practice of aerospace defense have not been based on defense systems only, but have been a harmonic mixture of offensive (strike) and defensive activities. Moreover, the premise of the Russian military seems to be that in the current state of affairs the defensive element by itself, even if augmented with strike capabilities, cannot ensure the successful repulsion of ASA, if not supported by nuclear capabilities. Thus, the Russian aerospace operation will have to learn not only to lean on defense-offense mix, but also to be preemptive in order to succeed, as the CGS has implied in comments on threat neutralization during a threatening period of war. ${ }^{80}$

Second, in contrast to the Western misnomer "anti-access/area denial," the proper professional term to describe the Russian theory of victory against an aerospace attack on the global and regional levels is "SORASA" - a strategic operation that encapsulates the abovementioned strike-defense dialectic. Despite the evolution it has undergone, the SORASA concept has been intact since the 1970s as the main frame of reference for operational planning and force employment against aerospace aggression. Within the Soviet-Russian intellectual tradition, it has been the main analytical framework for exploring military activities, past, present, and future. If the aim is to reflect the Russian strategic mentality, there is no other way to represent Russian thinking about military campaigns at the highest level of war.

Finally, contrary to the assertion by many Western analysts that a fait accompli strategy is driving Russian operations, there is apparently little space for the political-military leadership to consider this option. The issue is not even the lack of strategic intentions, which are indeed apparently absent; rather, it is insufficient capabilities. As of this writing, the Russian military perceives the capabilities on which SORASA rests as inadequate, and is therefore skeptical about its scale of effectiveness. Flaws in early warning, means of defense, strike capabilities, and C2 architecture hinder the ability to execute this theory of victory ideally. As the military wrestles with issues related to the operationalization of the offensive-defensive dialectics and a vaguely demarcated command authority, 81 it sees SORASA as posing more challenges than

\footnotetext{
${ }^{80}$ Michael Kofman, "It's Time to Talk about A2/AD: Rethinking the Russian Military Challenge," War on the Rocks; Kofman, "Assessing Russian Fait accompli strategy."

81 Sinikov, "O structure VKS oborony strany," pp. 91-93.
} 
opportunities. Until the Russian military brass has confidence in the ability of the armed forces to effectively neutralize the U.S. Prompt Global Strike (ASA), not to mention the ability to conquer and maintain strategic aerospace dominance, there is apparently little space for the political-military leadership to consider a fait accompli strategy, at least from the pure military (i.e. not a political point of view).

Although such a gambit is apparently unlikely, it is still hypothetically possible. If forced by circumstances, Moscow is likely to opt for it in a deterrence setting (preserving the status quo) rather than in a compellence setting (changing the status quo). If this coercion scheme materializes, it is more likely to be the result of hasty overreaction and inadvertent escalation than to be a preplanned move driven by the geopolitical assertiveness that many Russia watchers in the West have been attributing to Moscow. The Kremlin, which is advised by the military brass aware of these aerospace deficiencies, is likely to avoid such a risky eventuality.

An additional insight arises from the research. The case under scrutiny reveals that Russian reforms in the aerospace sphere often have been suboptimal, self-damaging, and irrational, because of such nonstrategic factors as the ambitions of the senior military leaders and parochial institutional interests that drove most of the transformations. Consequently, one can grasp the Russian theory of victory in aerospace defense-and in general, any other Russian military modernization and innovation-only in the context of intraservice and interservice competitions. Along the lines of Russian strategic culture, the contest over ownership often materializes in the form of doctrinal-conceptual debates between competing institutions, as they seek to justify scientifically the force posture they are actually advocating in order to promote their organizational ambitions. 


\section{Abbreviations}

\begin{tabular}{l|l} 
A3 & Anti-air artillery \\
AD & Air defense \\
AF & Air force \\
AoR & Area of responsibility \\
ASA & Aerospace aggression \\
C2 & Command and control \\
DA & Long-range aviation (dalniaia aviatsiia) \\
GS & General Staff \\
IA & Fighter aviation (istrebitel'naia aviatsiia) \\
MD & Military district \\
PRO & Anti-missile defense (protivoraketnaia oborona) \\
PVO & Air defense (protivovozdushnaia oborona) \\
PVO Strany & National Air Defense, service of the Soviet military \\
REB & Radio-electronic warfare (radioelektronnaia bor'ba) \\
RViA & Missile and Artillery Troops (roektnye voiska I artileriia) \\
RVSN & Strategic Mission Missile Forces (roketnye voiska strategicheskogo \\
& naznacheniia) \\
SAM & Surface to air missile \\
SASC & Strategic Aerospace Command \\
SO & Strategic operation \\
SORASA & Strategic Operation for Repelling Aerospace Aggression \\
TVD & Theater of military operations (teatr voennykh deistvii) \\
VKN & Aerospace attack (Vozdushno-kosmicheskoe napadenie) \\
VKO & Aerospace defense (Vozdushno-kosmicheskaia oborona) \\
VKS & Aerospace forces (Vozdushno-kosmicheskie sily) \\
VVS & Air Force (Voenno-vozdushnye sily) \\
&
\end{tabular}




\section{References}

Adamsky, Dmitry (Dima). "The Art of Net Assessment and Uncovering Foreign Military Innovations: Learning from Andrew Marshall's Legacy." Journal of Strategic Studies 43, no. 5 (2020): 611-644.

Aksenov, O.Iu., Iu.N. Tretiakov, and E.N. Filin. "Strategicheskie oboronitel'nye sistemy kak factor sderzhivania agressii." VM (2015).

Anoshko, Iurii, and Vladimir Barvinenko. “Starue problem novogo vida VS.” VKO, no. 3 (2015).

Barvinenko, V.V. “O popytkakh revizii polozhenii teorii VKO.” VM, no. 4 (Apr. 2018): 84-90.

Barvinenko, Vladimir. “I vnov' ostryi zud reformatorstva.” VKP 38 (Oct. 2, 2013).

_—_. “Osobaia rol' IA v VKO.” VPK, no. 14 (Apr. 16, 2014).

——_. "Vykhod Odin - V Konsentracii Usilii." VKO, no. 6 (2015): 18-27.

Belomytsev, A.V., M.G. Valeev, and N.L. Romas'. “O forme bor'by s vozdushno-kosmicheskim protivnikom." VM 5 (May 2014).

Borisko, S.N., and S.A. Goremykin. “Analiz Sostoianiia VKS Rossii.” VM, no. 1 (Jan. 2019): 2537.

Chekinov, S.G., V.I. Makarov, and V.V. Kochergin. "Zavoevanie I uderzhanie gospodstva v vozdukhe." VM, no. 2 (Feb. 2017).

Erokhin, I.V. Vozdushno-kismicheskaia sfera I vooruzhennaia bor'ba v nei. Tver': VA VKO, 2008.

Gareev, Makhmut. “Sozdanie VKO - Vazhneishaia Gosudarstvennaia zadachia.” 3 (2011).

Gavrilov, A.D. "Problemy bor'by s sovremennymi sredstvami vozdushnogo napadeniia.” zvestiia Rossiiskoi akademii raketnykh i artilleriiskikh nauk, no. 3 (2018): 19.

Goncharov, Andrei. "V perspective - protivokosmicheskaia operatsiia." VKO (June 15, 2014).

——_. "Voina budet vo vsekh sredakh." Voenno-kosmicheskaia oborona, no. 6 (Dec. 2, 2015).

Johnson, Dave. Russia's Conventional Precision Strike Capabilities, Regional Crises and Nuclear Thresholds. Livermore, CA: CGSR, 2018.

Khiupenen, Anatolii, and Sergei Pokladov. “Kto organizuet bor'bu na novom TVD.” VPK 19 (Dec. 2011). 
Khramchikhin, Aleksandr. Rethinking the Danger of Escalation: The Russia-NATO Military Balance. Carnegie Endowment for International Peace. Jan. 25, 2018.

Khramchikhin, Anatolii. "Voiska mirnogo neba." Nezavisimoe voennoe obozrenie (Nov. 22, 2018).

Kofman, Michael. "Assessing Russian Fait accompli strategy." Russian Analytical Digest 259 (Nov. 2020).

——_. "It's Time to Talk about A2/AD: Rethinking the Russian Military Challenge." War on the Rocks.

——_. "Russian A2/AD: is not overrated, just poorly understood." Russian Military Analysis Blog.

Kofman, Michael, Anya Fink, and Jeffrey Edmonds. Russian Strategy for Escalation Management. CNA. DRM-2019-U-022455-1Rev. 2020.

Kofman, Michael, and Anya Loukianova Fink. "Escalation Management and Nuclear Employemnt in Russian Miltary Strategy." War on The Rocks.

Korabel'nikov, A.P. “Sovremennye sposoby vozdushno-kosmicheskoi, protivovozdushnoi oborony obiektov.” VM, no. 1 (Jan. 2019).

Krinitskii, Iu. V. “Sovmeschenie vozdushnykh I strategicsheskih napravlenii.” VM, no. 10 (2005).

Krinitskii, Iurii. “Ob'ektivnaia real'nost' nashego vremeni.” Vozdushno-Kosmicheskii Rubezh (Aug. 22, 2017).

Krinitsky, Uirii. “Vozdushno-Kosmicheskii Teatr Voennykh Deistvii.” VPK 5 (Feb. 6, 2013).

Liaporov, V.N. “Kuznitse Voennykh Kadrov VKS - 60 let.” VM, no. 1 (2017).

McDermott, Roger, and Tor Bukkvol. "Tools of Future Wars." The Journal of Slavic Military Studies 31, no. 2 (2018): 191-213.

Milenin, O.V., and N.V. Golovzin. “Rozhdennaia v gody VOV.” VM, no. 2 (Feb. 2019): 108-120.

Novikov, R. A., and Iu. V. Krinitskii. “Organizatsionnaya Struktura Voisk, Vypolnyayushchikh Boevye Zadachi v Vozdushnoi (Vozdushno-Kosmicheskoi) Sfere,.” Voennaya Mysl', no. 2 (Feb. 2017).

"Osnovnue printsipy sozdaniia otsenki tekuschego I prognozongo uscherba vazhneishim ob'ektam sistemy strategicheskogo sderzhivaniia." VM, no. 6 (2015).

Ostankov, Vladimir. “Voiny Buduschego Nachinajutsia Segodnia.” VPK, no. 40 (Oct. 15, 2019). 
Ostapenko, O.N., S.V. Baushev, and I.V. Morozov. Informatsionno-Kosmicheskoe Obespechenie Gruppirovok Voisk (Sil) VS RF. St. Petersburg: Izd. Liubavich, 2012.

Reach, Clint, Vikram Kilambi, and Mark Cozad. Russian Assessments and Applications of the Correlation of Forces and Means. RAND. 2020.

Rudnenko, A.V., O.V. Milenin, and A.V.Bykardov. "K voprosu o gospodstve v vozdushnokosmicheskom prostranstve." VM, no. 3 (Mar. 2017).

Sinikov, A.A. “O structure VKS oborony strany.” VM, no. 7 (July 2017).

Sivkov, Konstantin. “Nebesnye bastiony.” VPK (Feb. 18, 2019).

Subbotin, V.A., and A.M. Shavelkin. "Edinaia sistema PVO - kakoi ei byt'?" VM, no. 10 (Oct. 2010): 6.

Valeev, M.G., E.N. Akhmerov, and D.E. Akhmerov. "Osnovnye podkhody k obosnovaniiu gruppirovok voisk PVO na strategicsheskih napravleniiakh.” VM, no. 9 (Sept. 2015): 53-58.

Whisler, Greg. "Strategic Command and Control of the Russian Armed Forces." Journal of Slavic Military Studies 33, no. 2 (2020): 237-258.

Zolotarev, V.A. Istoriia Voennoi Strategii Rossii. Moscow: Kuchkovo Pole, 2000. 


\section{This report was written by CNA's Strategy, Policy, Plans, and Programs Division (SP3).}

SP3 provides strategic and political-military analysis informed by regional expertise to support operational and policy-level decision-makers across the Department of the Navy, the Office of the Secretary of Defense, the unified combatant commands, the intelligence community, and domestic agencies. The division leverages social science research methods, field research, regional expertise, primary language skills, Track 1.5 partnerships, and policy and operational experience to support senior decision-makers.

CNA is a not-for-profit research organization that serves the public interest by providing in-depth analysis and result-oriented solutions to help government leaders choose the best course of action in setting policy and managing operations. 


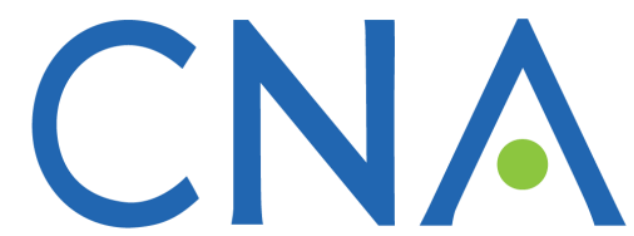

Dedicated to the Safety and Security of the Nation

IOP-2021-U-029278-Final

3003 Washington Boulevard, Arlington, VA 22201

www.cna.org • 703-824-2000 